Multidisciplinary

SCIENTIFIC JOURNAL OF

MARITIME RESEARCH

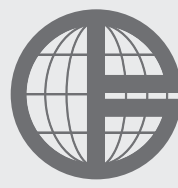

University of Rijeka

Faculty of Maritime

Studies Rijeka
Multidisciplinarni

znanstveni časopis

POMORSTVO

\title{
A Review of Leadership Behaviour of Maritime Officers in International Shipping
}

\author{
Ermal Xhelilaj ${ }^{1}$, Bledar Sakaj ${ }^{2}$ \\ ${ }^{1}$ University “Ismail Qemali” Vlore, L. Pavaresia, Skelë, Rruga Kosova, Vlorë 9401, Albania, e-mail: er.xhelilaj@gmail.com \\ ${ }^{2}$ Vlora Harbour Master Office, L. Pavaresia, Skelë, Vlorë 9401, Albania, e-mail: bledar_sakaj@yahoo.com
}

\section{ARTICLE INFO}

Review article

Received 4 May 2018

Accepted 27 May 2018

Key words:

Leadership

Maritime officers

Human resources

\section{Introduction}

An army of sheep led by a lion is better than an army of lions led by a sheep. Alexander the Great (Jane, 1915)

This renowned maxim emphasizes again the paramount importance that leaders reflect in terms of managing and steering human resources in different situations as well as diverse working environments. Therefore, it must be noted that leaders do not command excellence, they build excellence (Clark, 2008); and it is through this excellence-building process that leaders can be successful in accomplishing the organization objectives in different management levels. Considering the hardships and great responsibilities that working in maritime industry and international shipping represents nowadays, it is understandable the importance that signifies the leadership model of the management level working on-board ships.

In light of these considerations, the purpose of this research is to analyse whether there is an appropriate leadership approach for maritime working environment. In this respect, first, the diverse perspectives in defining leadership will be discussed. Then, an analysis will follow as to the controversy over leadership theories. Finally, an examination of leadership in light of young maritime officers as well as first and second mates and other officers working on board ship will conclude this paper coupled normally with some final remarks regarding the conclusions.

\section{Diverse Perspectives Regarding the Leadership Definition}

Defining leadership is fundamental towards carrying out a comprehensive assessment of the weaknesses and strengths characterizing ones leadership style. In this context, leadership has been defined in different ways from various authors. Thus, Bryman (1986) suggests that leadership involves a social influence process in which a person steers group members toward a goal (p. 2). Hunt (1986) maintains that leadership is the capacity to mobilize in competition or conflict a potential need in a follower, i.e. a relationship of mutual stimulation and ele- 
vation that converts arousal into engagement and results (p. 238).

Knootz \& Weihrich (1990), refer to it as the art of influencing people so that they will strive willingly and devotedly toward the achievement of group goals (p. 344). Ingstrup \& Crookall (1998), alternatively, consider leadership an important factor in shaping an organization, communicating and implementing new strategies, creating new alignments, and building corporate character (pp. 5253). Furthermore, Dixon (2003), remarks that leadership is the ability to influence the attitudes and behaviour of others in order to achieve organization's objectives with the maximum application of their abilities (p. 95).

More recently, other authors assert that by leadership we mean the capability to shape what followers in fact want to do (Platow at al, 2007). Richard (2007), at last, claims that leadership is about persuading followers to work together effectively to achieve the shared moral vision (p. 17). In any event, the definition presented in the study of Bellefontaine (2008), i.e. "the leadership lies in mastering a wide range of skills and how to make the most of opportunities to learn, lead, and achieve your goals" (p. 3 ) is the most comprehensive one, since it encompasses essential elements such as commitment, knowledge, and goal achievement, as well as reflects the substance of good leadership.

\section{Controversy over the Leadership Theories}

The earlier studies of leadership were largely based on attempts to identify the traits that leaders possessed (Dixon, 2003). Thus, the trait theory, by promoting the view that leadership is innate, aims to identify the person's physical, mental and personality traits (Armstrong \& Dawson, 1996) such as appearance, intelligence, adaptability, aggressiveness, self-confidence, persistence, initiative, and cooperativeness (Koontz \& Weihrich, 1990). In the following years the situational theory expanded trait approach to include the tasks to be completed, the factors affecting the situation both leader and followers are in, and the personality traits of the followers (Hunt, 1986). Nevertheless, in 1960s, the contingency theory based on Fielder (1967) research emerged - asserting that to become a leader it would require not only personal attributes and personalities, but also an active interaction between them and changing the situation.

The transformational theory which is concerned with emotions, values, ethics and needs of the followers, as well as with setting long-term goals came into existence in 1980s (Northouse, 2004), and soon after the transactional theory focusing on the organization management came into sight (Richard, 2007). Be that as it may, the common denominator of all these theories is that good leaders with sufficient character, determination and knowledge can triumph over whatever reality they confront (Platow at al, 2007). From the above discussion it appears that confusion and controversy persists among researchers.
In light of these considerations, it is submitted that trait-oriented theories lack clarity and support in explaining leadership, because it is difficult for all leaders to possess the totality of traits, while non-leaders may possess the majority or all of them. On the other hand, ambiguity prevails as to how all the aforementioned approaches conceptualize certain aspects of the leadership process; how they explain the link between styles and situations; as well as they are cumbersome to use in real-world settings (Northouse, 2004). Furthermore, the true power of leadership is not attributed solely to leaders, but comes from the synergy of many people working together towards a common objective (Richard, 2007).

At any rate, the view of this author is that the leadership style theory mainly suggested by authors such as Blake and Mouton, Dixon, Reddin, Harshey, Koontz \& Weihreich and as analysed and explained by Bellefontaine, perhaps reflects the most advantageous mechanism through which the analysis of the leadership style relevant for this author's working environment, and its relationship with human resource management may be best comprehended. For the purpose of this research, therefore, the four leadership styles based on the 'use of authority' - Autocratic, Democratic, Laissez Faire, and Paternalistic (Bellefontaine, 2008) will be analysed.

In the autocratic style, the leader is seen as a person who commands and expects compliance (Dixon, 2003); he is dogmatic and positive, and leads by the ability to withhold or give rewards and punishment (Koontz \& Weihrich, 1990). By determining what will be done, by whom, at what time and in what way (Armstrong \& Dawson, 1996), this leadership style gives high dependency on the leader, but creates demotivation and alienation of the staff (Bellefontaine, 2008). Moreover, this approach is considered as a performance inhibitor rather than an enhancer, and its effectiveness is limited to times of emergency and massive change (Richard, 2007).

The democratic leader consults with subordinates on actions and decisions and encourages the participation from them (Koontz \& Weihrich, 1990). He leads by positive endeavours to foster a team environment wherein all team members can reach their highest potential (Clark, 2008), creating thus a new order in which empowerment, innovation and freedom to act are the key features (Northouse, 2004). The group participation in setting objectives and establishing strategies is fundamental in this style (Armstrong \& Dawson, 1996) because helps motivation and involvement, but, at the same time, it may delay the decision-making process (Bellefontaine, 2008b).

Laissez Faire style is the approach wherein the leader provides to the subordinates a substantial degree of independence, leaving them to set their own goals and discover their own ways of achieving them (Dixon, 2003). One of the attributions of this approach is that the leader may delegate the authority and tasks to the subordinates (Ingstrup \& Crookall, 1998). The leader in this style may be a facilitator which provides relevant information to the subordinates, and what's more important, he acts as a con- 
tact with the external environment of the group (Koontz \& Weihrich, 1990).

As far as paternalistic type is concerned, Bellefontaine (2008) correctly observes that the leader acts as a father figure' in respect to his subordinates. He works to help, guide, protect and keep his followers happily working together as members of a family (Peterson, 2008). Additionally, the leader in this leadership type places a condescending trust and confidence in subordinates whom he motivates with rewards and some punishment (Dixon, 2003). Paternalistic leader makes decisions and retain close policy control, but, at the same time, may consult, allowing upward communications and perspectives from its subordinates (Bellefontaine, 2008b).

\section{Leadership in Light of the Position of Maritime Officers}

An effective leadership style is essential for the position of the maritime officers which are assigned on board a ship. Since in the beginning of their duty, most of young maritime officers, based on their inexistent experience, in general have a tendency to show a harsh behavior towards their subordinates, leading them perhaps with an iron hand, commanding and expecting compliance and obedience without considering their work and health conditions, fatigue level, or their view regarding relevant issues. Sometimes the punishment on board a ship is considered the most appropriate mechanism to make the subordinates comply even for tasks outside their area of expertise such as ordering a fatigued sailor who worked for twenty consecutive hours on board a ship to make extra work. The delegation of authority sometimes might be prohibited for young maritime officers even when this is allowed by the relevant IMO regulations such as ISPS Code (2002), ISM Code, STCW Convention (1978), SUA (1988) or SOLAS Convention (74/78). This problematic issue probably reflects the ship masters' lack of credibility towards the young maritime officers' abilities and experience, given their short time being on board a ship.

Although maritime officers, as leaders, should be generally characterized by an autocratic leadership type, yet, young maritime officers' behaviour is sometime inappropriate and ineffective; because, on board a ship is not only the senior officer alone who needs to be viewed as a leader, but also petty officers, cadets and sailors too need to demonstrate good leadership if the ship as a whole is to perform exceptionally (Richard, 2007). Moreover, as Eisenhower notes, you do not lead by hammering people over the head - that's assault, not leadership (Lewis, 2006). Richard (2007) also asserts that the 'big stick' must be avoided by a good leader, and that instead, recognition, respect and encouragement must be promoted among crew members. Additionally, excellent leadership depends basically on constituent cooperation and support, successful delegation of the authority and on the communication effectiveness (Platow at al, 2007; Ingstrup \& Crookall, 1998).
For good leadership, traits such as maturity, bearing, fair-minded, tact, justice, integrity, confidence, coolness, goodwill, and candour must be the guiding light (Clark, 2008). Bellefontaine (2008), in this regard notes that emotional stability and intelligence and passion are key traits for a superior leadership. In this context, Koontz \& Weihrich, (1990) consider the fundamental understanding of people, and the climate the leader develops as essential ingredients of leadership (p.345). Finally, Northouse (2004) maintains that good leaders respect and serve others, build good cooperation, and promote impartiality. In this respect, it is submitted that all these crucial traits are essential for maritime officers' leadership style.

Nonetheless, from the above discussion, conclusions may be drawn that perhaps there is no perfect leadership style that might be suitable for all sorts of situations. Therefore, the effectiveness of the leadership style depends on the demand of the situation; particularly, in the maritime working environment, which implies high risk for accidents, harsh weather and working conditions, extra responsibility, increased fatigue and stress, and social isolation. Thus, the Autocratic style of leadership may be only appropriate where decisions need to be made quickly and decisively, as well as when total absence of discipline exists among subordinates. On the other hand, the pre-dominated view is that the Democratic style appears to be more suitable for good leadership (Dixon, 2003), but in changing situations may be ineffective towards rapid decision-making (Bellefontaine, 2008). Similarly, in spite of the fact that Laissez Faire style might embrace effective traits necessary for a good leadership, this approach may again offer minimum direction and discipline, particularly, for emergency situations.

\section{Conclusion}

As a result, there are diverse perspectives and opinions among scholars in defining leadership. At any rate, the definition suggested by Bellefontaine in his human resource study is considered the most complete according to the authors, because it encompasses essential leadership components and contains the pith and substance of the subject. Additionally, numerous leadership theories proposed by many researchers may lead to the conclusions that inconsistency, confusion and perhaps controversy persists among scholars in analysing, defining and appreciating the art of leadership.

Be that as it may, the leadership style theory based on 'use of authority' which consists of the autocratic, democratic, laissez faire, and paternalistic style reflects perhaps the potential mechanism through which the analyses of young maritime officers' leadership style and its relationship with human resource management may be best comprehended.

Moreover, due to the lack of the work experience, young maritime officers generally reflect an autocratic leadership style, which from the above discussion has been generally considered to be ineffective and unfruitful. As a final point, each leadership style has its weaknesses and strength. 
Therefore, the effectiveness of the leadership style depends on the demand of the situation and the specific requirements, particularly in the maritime working sector - commonly characterized by a harsh environment.

\section{References}

[1] Armstrong, P. \& Dawson, C. (1996). People in organizations. ( $5^{\text {th }}$ ed.). Kings Ripton, U.K.: ELM Publications.

[2] Bellefontaine, N.A. (2008). Human Resource Management: Becoming an Effective Leader. Unpublished lecture handout, World Maritime University, Malmo, Sweden.

[3] Blanchard, K.H., Zigarmi, P. \& Zigarmi, D. (1985). Leadership and the one minute manager: increasing effectiveness through situational leadership. ( $1^{\text {st }}$ ed.). New York: Morrow.

[4] Bryman, A. (1986). Leadership and Organizations. London; Boston: Routledge \& K. Paul.

[5] Clark, D. R. (2008). Concepts of Leaderships. Retrieved August 25, 2008 from the World Wide Web: http://nwlink. com/ donclark/leader/leadcon.html.

[6] Clark, D. R. (2008). Leadership - Character and Traits. Retrieved August 24, 2008 from the World Wide Web: http:// nwlink.com/ donclark/leader/leadchr.html.

[7] Dixon, R. (2003). The management task. (3rd ed.). Boston, MA; Oxford: Butterworth-Heinemann.

[8] Fielder, F.E. (1967). A theory of Leadership Effectiveness. London; New York: McGraw-Hill Book Co.
[9] Hunt, J.W. (1986). Managing people at work: a manager's guide to behavior in Organizations. London; New York: McGraw-Hill Book Co.

[10] Ingstrup, O. \& Crookall, P. (1998). The three pillars of public management: secrets of sustained success. Montreal; London: McGill-Queens University Press.

[11] Jane, F.T. (1915). The British Battle Fleet: Its Inception and Growth Throughout the Centuries to the Present Day, as cited from the article Alexander the Great. Retrieved August 22, 2008 from the World Wide Web: http://en.wikiquote.org/ wiki/Alexander_the_Great.

[12] Koontz, H. \& Weihrich, H. (1990). Essentials of management. ( $5^{\text {th }}$ ed.). New York: McGraw-Hill Publishers.

[13] Kotter, J.P. (1996). Leading change. Boston, MA, USA: Harvard Business School Press.

[14] Lewis, J.J. (2006). Leadership Quotes - Wisdom Quotes: Quotations to inspire and challenge. Retrieved August 21, 2008 from the World Wide Web: http://www.wisdomquotes.com/cat_leadership.html\#cat.

[15] Northouse, P.G. (2004). Leadership Theory and Practice. Thousand Oaks, Cal.: Sage Publication, Inc.

[16] Platow et al. (2007). The New Psychology of Leadership. Scientific American Mind, August 2007 Issue.

[17] Peterson, M. (2008). Leadership Styles. Retrieved August 21, 2008 from the World Wide Web: http://ezinearticles. com/?Leadership-Styles\&id=207329

[18] Richard, J. (2007). Leadership throughout: how to create successful enterprise. London: The Nautical Institute. 